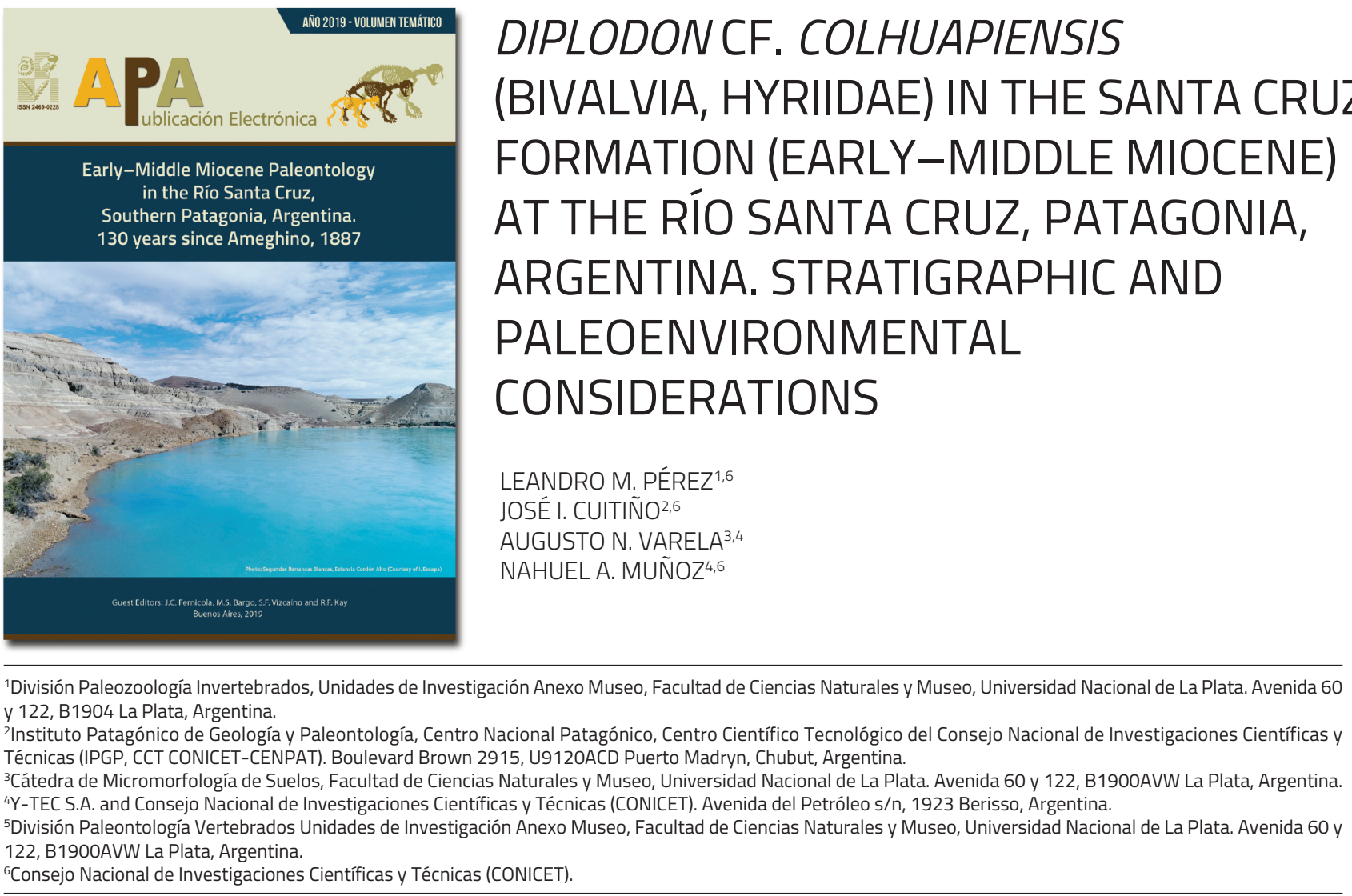

Recibido: 15 de marzo 2019 - Aceptado: 16 de julio 2019

Para citar este artículo: Leandro M. Pérez, José I. Cuitiño, Augusto N. Varela, and Nahuel A. Muñoz (2019). Diplodon cf. Colhuapiensis (Bivalvia, Hyriidae) in the Santa Cruz Formation (Early-Middle Miocene) at the Río Santa Cruz, Patagonia, Argentina. Stratigraphic and paleoenvironmental considerations. Publicación Electrónica de la Asociación Paleontológica Argentina 19 (2): 34-47.

Link a este artículo: http://dx.doi.org/10.5710/PEAPA.16.07.2019.283

DESPLAZARSE HACIA ABAJO PARA ACCEDER AL ARTÍCULO

Otros artículos en Publicación Electrónica de la APA 19(2):

\section{J.C. Fernicola, S.F. Vizcaíno}

CINGULATES (MAMMALIA, XENARTHRA) OF THE SANTA CRUZ FORMATION (EARLY-MIDDLE MIOCENE, BURDIGALIAN) FROM THE RÍO SANTA CRUZ, ARGENTINE PATAGONIA

\section{M.S. Bargo et al.}

EARLY MIOCENE SLOTHS (XENARTHRA, FOLIVORA) FROM THE RÍO SANTA CRUZ VALLEY (SOUTHERN PATAGONIA, ARGENTINA). AMEGHINO, 1887 REVISITED

Asociación Paleontológica Argentina Maipú $6451^{\circ}$ piso, C1006ACG, Buenos Aires República Argentina Tel/Fax (54-11) 4326-7563 Web: www.apaleontologica.org.ar

J.C. Fernicola et al.

ANALYSIS OF THE EARLY-MIDDLE MIOCENE MAMMAL ASSOCIATIONS AT THE RÍO SANTA CRUZ (PATAGONIA, ARGENTINA) 


\title{
DIPLODON CF. COLHUAPIENSIS (BIVALVIA, HYRIIDAE) IN THE SANTA CRUZ FORMATION (EARLY-MIDDLE MIOCENE) AT THE RÍO SANTA CRUZ, PATAGONIA, ARGENTINA. STRATIGRAPHIC AND PALEOENVIRONMENTAL CONSIDERATIONS
}

\author{
LEANDRO M. PÉREZ ${ }^{1,6}$, JOSÉ I. CUITIÑO2,6, AUGUSTO N. VARELA ${ }^{3,4}$, AND NAHUEL A. MUÑOZ
}

\begin{abstract}
1'División Paleozoología Invertebrados, Unidades de Investigación Anexo Museo, Facultad de Ciencias Naturales y Museo, Universidad Nacional de La Plata. Avenida 60 y 122, B1904 La Plata, Argentina. pilosaperez@gmail.com

${ }^{2}$ Instituto Patagónico de Geología y Paleontología, Centro Nacional Patagónico, Centro Científico Tecnológico del Consejo Nacional de Investigaciones Científicas y Técnicas (IPGP, CCT CONICET-CENPAT). Boulevard Brown 2915, U9120ACD Puerto Madryn, Chubut, Argentina. jcuitino@cenpat-conicet.gob.ar

${ }^{3}$ Cátedra de Micromorfología de Suelos, Facultad de Ciencias Naturales y Museo, Universidad Nacional de La Plata. Avenida 60 y 122, B1900AVW La Plata, Argentina.augustovarela@cig.museo.un/p.edu.ar

${ }^{4}$ Y-TEC S.A. and Consejo Nacional de Investigaciones Científicas y Técnicas (CONICET). Avenida del Petróleo s/n, 1923 Berisso, Argentina.

${ }^{5}$ División Paleontología Vertebrados Unidades de Investigación Anexo Museo, Facultad de Ciencias Naturales y Museo, Universidad Nacional de La Plata. Avenida 60 y 122, B1900AVW La Plata, Argentina.nahuelmunoz@fcnym.unlp.edu.ar

${ }^{6}$ Consejo Nacional de Investigaciones Científicas y Técnicas (CONICET).
\end{abstract}

\begin{abstract}
The Santa Cruz Formation (Early-Middle Miocene) is one of the most widespread sedimentary units of the Argentine Patagonia. This unit contains an abundant and taxonomically diverse fossil vertebrate fauna, especially in mammals. Thus, the paleoecological and paleoenvironmental information derives mainly from the analysis of the vertebrate assemblages, as well as from the ichnological and paleobotanical evidence. The record of freshwater bivalves assigned to the species Diplodon cf. colhuapiensis Ihering, 1903 from the Santa Cruz Formation, collected in the locality of Barrancas Blancas (Estancia Santa Lucía), at Río Santa Cruz, allows us to infer the particular paleoenvironmental conditions setting during the deposition of the bearing levels. Considering this record, we propose that Diplodon, which was originally assigned to the "Sehuenense stage" (piso sehuenense of F. Ameghino), could have come from the Early-Middle Miocene of the Santa Cruz Formation. In this sense, the specimens referred to Diplodon cf. colhuapiensis suggest the existence of an established community of Hyriidae mollusks at the upper-middle levels of the Santa Cruz Formation. The presence of freshwater bivalves suggests that the depositional environment of this unit included the existence of water courses. The identification of the genus in the Santa Cruz Formation validates its presence in the Early Miocene and extends its southern distribution to the latitude of Río Santa Cruz ( 50 S).
\end{abstract}

Key words. Diplodon. Hyriidae. Sehuenense stage. Neogene. Santa Cruz Formation. Argentine Patagonia.

Resumen. DIPLODONCF. COLHUAPIENSIS (BIVALVIA, HYRIIDAE) EN LA FORMACIÓN SANTA CRUZ (MIOCENO TEMPRANO-MEDIO) EN EL RÍO SANTA CRUZ, PATAGONIA, ARGENTINA. CONSIDERACIONES ESTRATIGRÁFICAS Y PALEOAMBIENTALES. La Formación Santa Cruz (Mioceno Temprano-Medio), es una de las unidades sedimentarias más extendidas de la Patagonia argentina. Esta unidad contiene una gran abundancia y diversidad taxonómica de vertebrados fósiles, especialmente de mamíferos. De esta manera, la información paleoecológica y paleoambiental proviene principalmente del análisis de la asociación de vertebrados, como también la evidencia icnológica y paleobotánica. El registro de bivalvos de agua dulce asignados a la especie Diplodon cf. colhuapiensis lhering, 1903 de la Formación Santa Cruz, recolectado en la localidad Barrancas Blancas (Estancia Santa Lucía), cerca del Río Santa Cruz, permite inferir las condiciones paleoambientales de la depositación de sedimentos de los niveles portadores de los especímenes. Teniendo en cuenta estos restos, proponemos que el material de Diplodon originalmente asignado al "piso Sehuenense" (piso sehuenense de F. Ameghino), podrían provenir del Mioceno Temprano-Medio de la Formación Santa Cruz. En este sentido, el registro de Diplodon cf. colhuapiensis confirma la existencia de una población establecida de moluscos de la familia Hyriidae en los niveles medio-altos de la Formación Santa Cruz. La presencia de bivalvos de agua dulce, probablemente habitando canales fluviales, sugiere la existencia de cursos de agua bien desarrollados en el ambiente depositacional de la unidad. La identificación del género en la Formación Santa Cruz valida su presencia en el Mioceno Temprano y extiende su distribución sur a la latitud actual del Río Santa Cruz ( 50 S).

Palabras clave. Diplodon. Hyriidae. Piso Sehuenense. Neógeno. Formación Santa Cruz. Patagonia argentina. 
The Santa Cruz Formation (SCF), Burdigalian-early Langhian in age, is one of the most widespread sedimentary units in the Argentine Patagonia and, particularly, in the Austral (or Magallanes) Basin, Province of Santa Cruz (Feruglio, 1949; Tauber, 1994; Matheos and Raigemborn, 2012; Perkins et al., 2012; Raigemborn et al., 2015; Cuitiño et al., 2016). This lithostratigraphic unit represents a continental sedimentation lapse associated with the rise of the Southern Patagonian Andes (Ghiglione et al., 2016). Its fossil richness gave it a great geological and paleontological appeal and has spurred the interest of naturalists since the end of the $19^{\text {th }}$ century (e.g., Ameghino, 1893, 1906; Hatcher, 1900; Feruglio, 1949; Vizcaíno et al., 2013). It contains a great abundance and diversity of fossil vertebrate remains, especially mammals (Tauber, 1997; Kay et al., 2012), and most of the paleoecological and paleoenvironmental information of this unit derives from the analysis of the vertebrate fauna (Kay et al., 2012) together with sedimentological and paleopedological analyses of the stratigraphic sequences (Raigemborn et al., 2018; Montalvo et al., 2019). The faunal association, mostly represented by mammalian remains, encouraged the definition of the Santacrucian "mammalian age" of South America (Ameghino, 1906; Pascual et al., 1965; Fernicola et al., 2019). Associated with the vertebrates, the SCF contains other fossil taxa; i.e., plants (Brea et al., 2017), marine mollusks in the lower levels (Griffin and Parras, 2012) and continental pulmonate gastropods (Rodríguez et al., 2012). Likewise, ichnofossils produced by continental invertebrates and mammals have also been described (Krapovickas, 2012; Zapata et al., 2016; Raigemborn et al., 2018, 2019; Cuitiño et al., 2019).

The order Unionida (Bivalvia) is widespread in the Neotropical region, in which it presents the greatest diversity, with 249 species distributed in eight families (Torres et al., 2018). It is found throughout South America, from the Equator to the Patagonian lakes and rivers of Argentina and Chile. The family Hyriidae, in particular, is represented in South America by seven genera (Miyahira et al., 2017). Two of them are present in Argentina: Diplodon and Castalia, the former with 14 living species and the latter, with only two (Torres et al., 2018). Diplodon is well-known in the Argentine Patagonia by several fossil findings reported from different stratigraphic units throughout the Cenozoic. Parras and Griffin (2013) reported Diplodon bodenbenderi Doello Jurado, 1927, from locations in northern Neuquén and southern Mendoza, and assigned all of them to the Cretaceous-Paleogene. Ihering (1903, p. 217), reported Diplodon colhuapiensis Ihering, 1903, from "Colhuapi" (Province of Chubut), based on findings by Carlos Ameghino, and "Río Sehuen" (Province of Santa Cruz), by Rudolf Hauthal (sensu Parodiz, 1969), and referred it to the "Salamanqueano" (Cretaceous) and "Sehuenense" (Upper Cretaceous), respectively (vide infra). Years later, Parodiz (1969) reassigned the same materials to a Paleogene age (Paleocene). Manceñido, and Damborenea (1984) reported three species from locations in central-west Río Negro: Diplodon (Prodiplodon) amphitheatri Manceñido and Damborenea, 1984; Diplodon (Antediplodon?) bodenbenderi Doello Jurado, 1927; and Diplodon pehuenchensis Doello Jurado, 1927, while Morton, and Sepúlveda (1988) reported Diplodon aff. colhuapiensis Ihering, 1903, Diplodon aff. pehuenchensis Doello Jurado, 1927, and Diplodon aff. oponcitonis Pilsbry and Olsson, 1935 from the north-west of the Province of Chubut.

The aim of this paper is to report freshwater bivalves assigned to the species Diplodon cf. colhuapiensis Ihering, 1903 from the SCF, which were collected in Barrancas Blancas (Estancia Santa Lucía) in the Río Santa Cruz area (Fig. 1). From this record, we also infer the paleoenvironmental conditions of the fossil bearing beds, considering both the depositional environment of the sedimentary materials and the ecological requirements of the genus Diplodon. The age of the holotype of $D$. colhuapiensis is also discussed.

\section{STUDY AREA AND GEOLOGICAL SETTING}

Río Santa Cruz is located in southern Santa Cruz, where the SCF is sporadically exposed (Fig. 1). This unit stretches from the foothills of Cordillera de los Andes (Lago Argentino/Río Turbio region) to the cliffs along the Atlantic coast, especially between Río Gallegos and the Parque Nacional Monte León (Fig. 1). In all the localities in which its base is visible, it is concordantly overlying the marine sediments of the Early Miocene assigned to the Patagonian transgression (Feruglio, 1938; Cuitiño and Scasso, 2010a,b; Cuitiño et al., 2012, 2016; Griffin and Parras, 2012; Raigemborn et al., 2015).

The SCF essentially consists of fine-grained and well- 


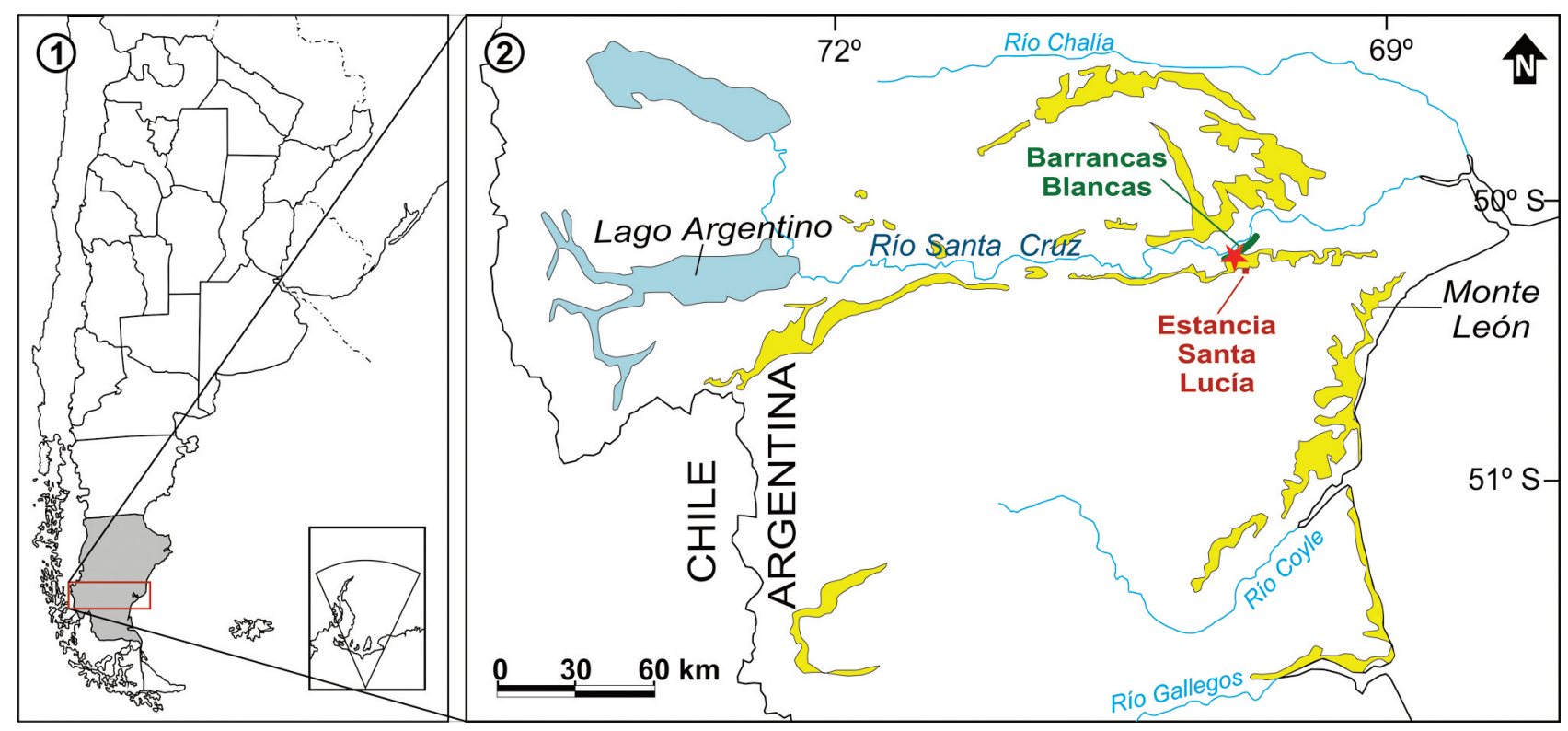

Figure 1.1, Location map of the study area in Argentina. Province of Santa Cruz indicated in gray. 2, Study area with extension of the outcrops of the Santa Cruz Formation (yellow). The Estancia Santa Lucía site is indicated with a square. The locality Barrancas Blancas is indicated with a green bar. The geographic provenance of the studied material is indicated with a red star.

stratified sediments, mostly silts and fine sandstones, with poorly developed paleosol levels and a high proportion of fine pyroclastic material intercalated in the form of discrete levels of tuffs or mixed with epiclastic sediments. These sediments are interpreted as deposits of a low-gradient fluvial system with extensive floodplains and low sinuosity anastomosed channels (Raigemborn et al., 2015, 2018; Cuitiño et al., 2016, 2019; Zapata, 2018).

The age of the SCF is estimated on the basis of stratigraphic relationships and numerous ${ }^{40} \mathrm{Ar} /{ }^{39} \mathrm{Ar}$ and $\mathrm{U} / \mathrm{Pb}$ radiometric datings, which indicate a Burdigalian-early Langhian age range (17.45-15.3 Ma) for the study area (Perkins et al., 2012; Cuitiño et al., 2016, 2019). Westward, along the foothills of the Southern Patagonian Andes, the sediment depositions of the SCF are also BurdigalianLanghian, approximately at $19 \mathrm{Ma}$, and would have continued until approximately $14 \mathrm{Ma}$ (Cuitiño et al., 2012, 2016; Bostelmann et al., 2013).

Between the mountain range to the West and the coast to the East, the SCF crops out in several localities of the valley of Río Santa Cruz, of which some have recently been the object of paleontological (Fernicola et al., 2014, 2019, and other articles in this volume) and geological (Cuitiño et al.,
$2016,2019)$ studies. The remains of Diplodon herein described come from Estancia Santa Lucía (50 12' 59" S; 69 44' 51" W). This section (Fig. 2.1) is located at the westernmost area of the locality named Barrancas Blancas by Carlos Ameghino (see Fernicola et al. 2014, 2019). In the study area, the SCF is composed of light green and yellowish silts with little development of paleosols, which are intercalated with dark gray to brown, fine- to medium-grained sandstones arranged in lenticular banks (Fernicola et al., 2014; Cuitiño et al., 2016, 2019). The SCF concordantly overlays the Monte León Formation and is $150 \mathrm{~m}$ thick (Fernicola et al., 2014). The top of the unit is truncated by Quaternary terraced conglomerate deposits of Río Santa Cruz. Bivalves were found $3.5 \mathrm{~km}$ southwest of the section showed by Fernicola et al. (2014).

\section{The Piso Sehuenense of F. Ameghino}

Ameghino (1893) described plesiosaur teeth (Polyptychodon patagonicus) in what he then called the Santa Cruz Formation. Regarding its stratigraphic and geographic origin, Ameghino (1893, p. 76) indicated that "La formación que he designado con el nombre de Santacruceña, ocupa la mayor parte de la región de la Patagonia Austral, que cruzan los ríos Santa Cruz, 

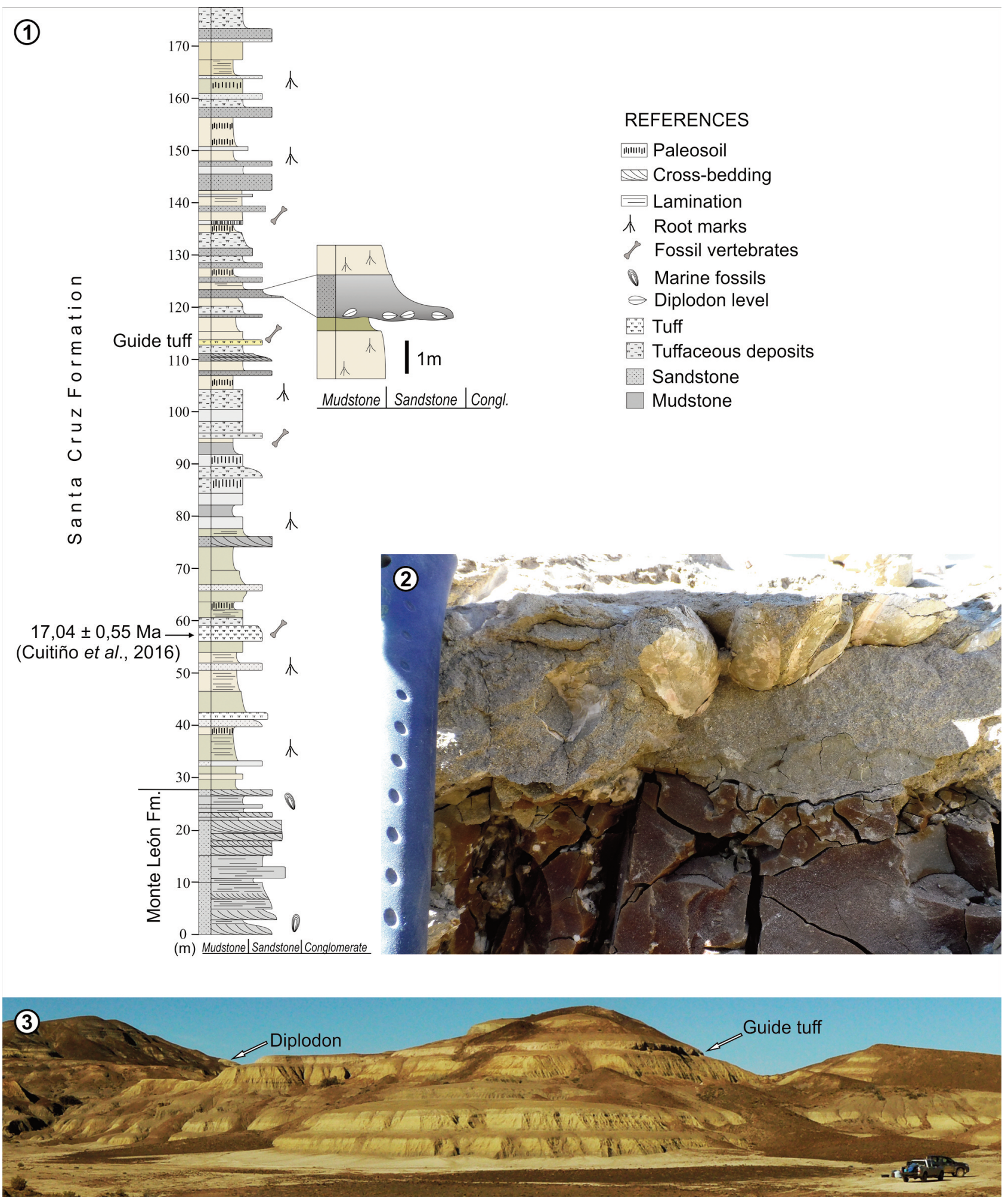

Figure 2. 1-3, The study section of the Santa Cruz Formation in Barrancas Blancas (Early Miocene-Burdigalian). 1, The section includes $\sim 150$ $\mathrm{m}$ of silicoclastic rocks, sandy to silty beds with little development of paleosols. 2, level with the Diplodon specimens within the sedimentary matrix. 3, general view of the outcrops indicating the fossiliferous level and the dated tuff. 
Sehuen y Gallegos" (The formation that I have designated with the name of Santacruceña occupies most of the region of Southern Patagonia, crossed by the Santa Cruz, the Sehuen, and the Gallegos rivers). Along Río Sehuen (= Chalía), the Cretaceous Mata Amarilla Formation is exposed (Feruglio in Fossa Mancini et al., 1938; Arbe, 1989, 2002; O'Gorman and Varela, 2010; Varela et al., 2012) associated with the Santa Cruz Formation. This would indicate that the "Formación Santacruceña" of Ameghino (1893) is only in part equivalent to what is now known as the Santa Cruz Formation, and that Ameghino also included what is now known as the Mata Amarilla Formation in his "Formación Santacruceña" (Ameghino, 1893, p. 76).

Ameghino's interpretation is understandable considering the lithological similarity of both formations. Regarding the age, he referred the "Formación Santacruceña" to the "Lower Eocene (Paleocene)" (Ameghino, 1893, p. 76). In the introduction, Ameghino (1893) referred to the problematic association of primates and other clearly Tertiary mammals together with Cretaceous taxa in this formation. Therefore, the association of Polyptychodon patagonicus teeth with mammals was based only on a lithostratigraphic similarity.

Ameghino (1906) separated the section of Río Sehuen from his Santa Cruz Formation and named the former the "Sehuenense o Sehuénéen" stage. In the same work, he published the map made by his brother, Carlos, and continued to cite the Cretaceous taxa as coming from the "Sehuenense" and not from the Santa Cruz Formation.

\section{MATERIALS AND METHODS}

The systematic classification of the living species of Unionida, from Argentina, follows Torres et al. (2018).

In order to place the material in a stratigraphic/paleoenvironmental context, a Selley-type sedimentological column was logged, highlighting grain size, sedimentary structures, pedogenetic features, discontinuities and strata shapes, among others. Additionally, we searched for elements that would help to correlate and integrate the stratigraphic information with the Barrancas Blancas section published by Fernicola et al. (2014; see also Cuitiño et al., 2019) and dated by Cuitiño et al. (2016).

The analysis of the sedimentary matrix bearing the fossils was performed with a Nikon Eclipse E200 binocu- lar petrographic microscope with an associated Leica D camera FC290 HD; the images were taken with and without polarized light. This analysis was carried out at Centro de Investigaciones Geológicas (CIG-CONICET), La Plata. The specimens used for comparison, housed in the Museo Argentino de Ciencias Naturales "Bernardino Rivadavia" collection, were photographed with a Canon EOS XSi camera. The measurements of the specimens photographed for comparison were taken with the ImageJ 1.50i software (Schneider et al., 2012).

Institutional abbreviations. CM, Carnegie Museum of Natural History, Pittsburgh, United States of America; ICZN, International Commission on Zoological Nomenclature; MACN, Museo Argentino de Ciencias Naturales “Bernardino Rivadavia", Ciudad Autónoma de Buenos Aires, Argentina; MPM, Museo Regional Provincial "Padre Manuel J. Molina", Río Gallegos, Argentina; SALMA, South American Land Mammal Age.

\section{SYSTEMATIC PALEONTOLOGY}

Class Bivalvia Linnaeus, 1758

Subclass Palaeoheterodonta Newell, 1965 Order UNIONIDA Gray, 1854

Superfamily HyRIOIDEA Swainson, 1840

Family HYRIIDAE Swainson, 1840

Genus Diplodon Spix in Wagner, 1827

Type species. Diplodon ellipticus Spix in Wagner, 1827; OD. Recent, Rio São Francisco, Brazil (see Miyahira et al., 2013).

Diplodon cf. colhuapiensis lhering, 1903

(Fig. 3.1-5)

1903 Diplodon colhuapiensis sp. n.; VON IHERING, pags. 216217, fig. 2.

1907 Diplodon colhuapiensis IH.; VON IHERING, pag. 466.

1914 Diplodon colhuapensis IH.; VON IHERING, pag. 36.

1969 Diplodon colhuapiensis lhering; PARODIz, pags. 53-54, pl. 1, figs. 1-4.

Type material. Following the article 73.1.1 of the ICZN and based on Ihering (1903, p. 217 "L'exemplaire typique figure a..."), we believe the holotype (CM 61-137) was deposited by Parodiz in the collection of the Carnegie Museum of 
Natural History in May 1961 (Fig. 4.1). The measurements of the holotype are: length of $52 \mathrm{~mm}$, height of $30 \mathrm{~mm}$, width of $19 \mathrm{~mm}$ (taken from lhering, 1903, page 216). Part of the presumed lot of cotypes (sic cotypo, in the oldest tag) (Paratypes? MACN-Pi 295) remained in the División de Paleontología de Invertebrados of the MACN (Fig. 4.2-3). This link with the material of the CM is made from one of the labels associated with the material in the MACN, which indicates that the material is "cotype" together with the indication "C. Ameghino 1903". According to this label, it is clear that the specimens come from the "formaçaõ do Pyrotherium" (sic in the MACN 295 tag) Salamanquense. In another label, the age assigned to the material appears; i.e., "Cretácico superiorSalamanquense", and states that it belongs to the Ihering collection. The specimens that conform the "type material" were collected by C. Ameghino in the locality of Colhue Huapi, Province of Chubut, Argentine Patagonia, and were initially published by lhering (1903, p. 216), who stated that "M. C. Ameghino a recueilli plusieurs exemplaires de cette espéce á Colhuapi" (Mr. C. Ameghino has collected several samples of this species in Colhuapi).

In the same article in which he names $D$. colhuapiensis, Ihering (1903) indicated that "J'ai reçu des moules, correspondant dans leur forme au Diplodon colhuapiensis, de M. le docteur R. Hauthal qui les a trouvés au Río Sehuen, et dont le plus grand exemplaire a une longueur de $58 \mathrm{~mm}$ " (I received molds, corresponding in form to the Diplodon colhuapiensis, from Mr. Dr. R. Hauthal, who found them at Río Sehuen, and from which the largest specimen has a length of $58 \mathrm{~mm}$ ). In a later work (1907, p. 466), Ihering indicated that "J'en ai reçu aussi quelques moules du Rio Séhuen, recueillis par le Dr. R. Hauthal" (I also received some molds from Rio Séhuen, collected by Dr. R. Hauthal), suggesting that he had a second collection. This last one probably has the number MACN-Pi 296 and includes four internal molds from Río SehuenPatagonia, "Upper Cretaceous" (the file indicates: Roth leg, coll. Ihering). Thus, Ihering (1903) considered that all the aforementioned material belonged to the same species, $D$. colhuapiensis.

As Parodiz (1969, p. 40) said, these "Roth" specimens could have been mixed, meaning that they came from different stratigraphic levels and localities of Southern Pata- gonia, giving way to the confusion about the stratigraphic ages and units in which this species can be found.

Referred material from "Estancia Santa Lucía". Five incomplete specimens, MPM-Pi 19425 (Fig. 3.1-5), and several additional fragments within the rocky matrix. All specimens were found in situ but accumulated in a chaotic manner at the base and encased in a psamo-pelitic matrix, mostly with both valves joined. They were found together with somewhat fragmented shells with diagenetic alteration of the outer surfaces of the valves. As discussed by Miyahira et al. (2017), the most important features of the shells are their umbo position, their umbonal sculpture and hinge details. The characters preserved in MPM-Pi 19425 prevent a more precise taxonomic assignment.

Geographic and stratigraphic provenance. Barrancas Blancas (Estancia Santa Lucía), Province of Santa Cruz (Argentina), Santa Cruz Formation (Early Miocene).

Description of MPM-Pi 19425. Sub-elliptical medium sized shell, equivalve, inequilateral, slightly compressed, with the anterior margin rounded and the posterior margin slightly acute. Dorsal edge slightly convex, posterior ventral margin somewhat curved. Slightly pronounced prosogyrous umbo with a small sub-umbonal cavity. Thin shell, smooth outer surface, with tenuous regular commarginal concentric lines. Dorsal posterior carina weakly marked. Impressions of subcircular isomyarian adductor muscles poorly marked. Poorly differentiated cardinal tooth. The inner surface retains part of the pearly layer. The average dimensions for adult individuals are: length of $\sim 76 \mathrm{~mm}$; height of $\sim 43 \mathrm{~mm}$; width of $\sim 25 \mathrm{~mm}$ (measurements taken on 3 specimens).

Comments and comparison. The material shows all the characteristics of the genus Diplodon with some features comparable to the holotype of Diplodon colhuapiensis. Although the holotype and the rest of the specimens originally referred to the species $D$. colhuapiensis correspond to molds, they have features that are recognizable in the specimens of MPM-Pi 19425. Considering the molds labelled "Cotypos" (MACN-Pi 295) as part of the original material of the species nominated by Ihering (1903), as suggested by Parodiz (1969, p. 54), a more complete comparison with the specimens MPM-Pi 19425 is possible. The new specimens are larger than the type material of $D$. colhuapiensis and the lot 
of "cotypes" (vide supra), whose size ranges from 58 to 35 $\mathrm{mm}$ in length, 33 to $21 \mathrm{~mm}$ in height and 17 to $10 \mathrm{~mm}$ in width. The rest of the characters recognized in MPM-Pi 19425 do not present differences with the type material of
D. colhuapiensis that are significant enough to justify the separation of this sample into a different taxonomic entity. This morphological correspondence could be asserted after establishing comparisons with a greater number of speci-
(1)

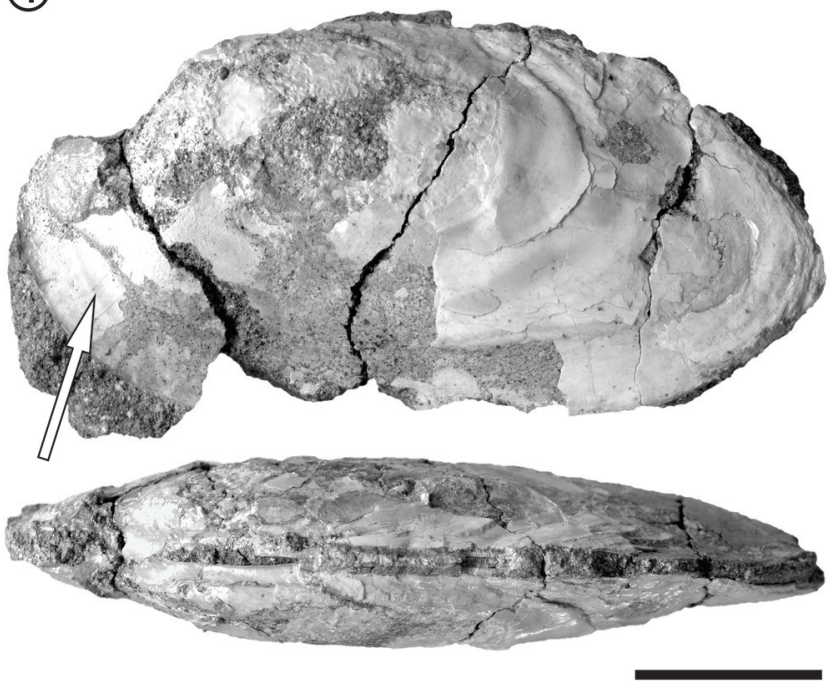

(3)
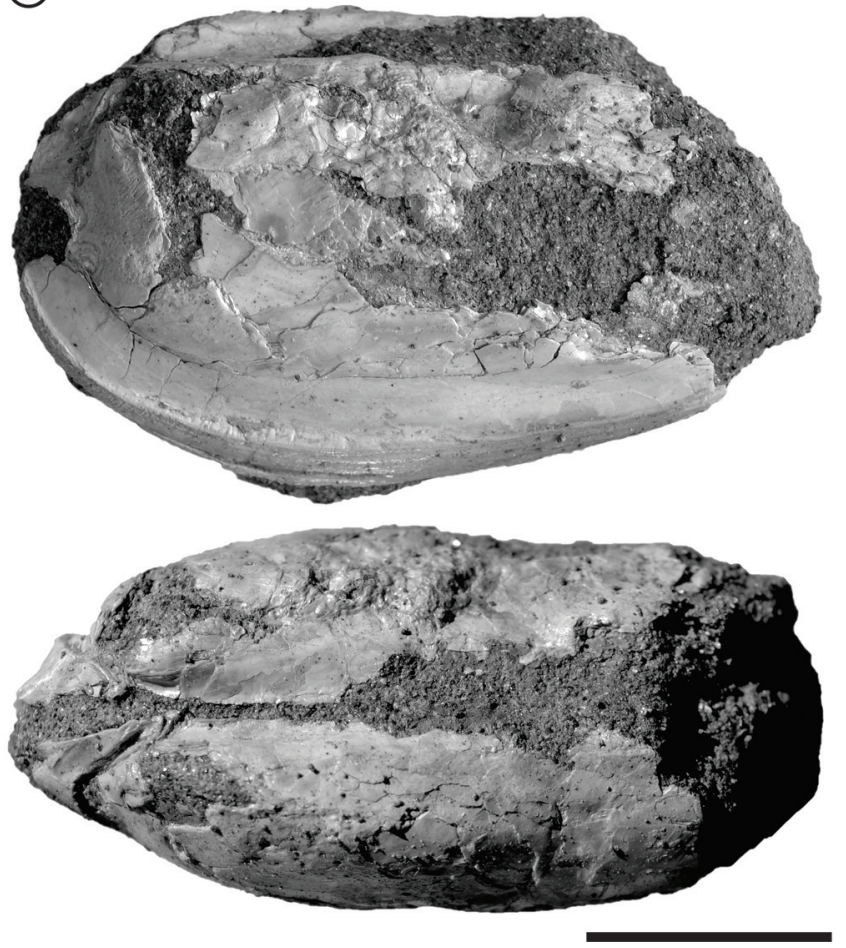

(2)

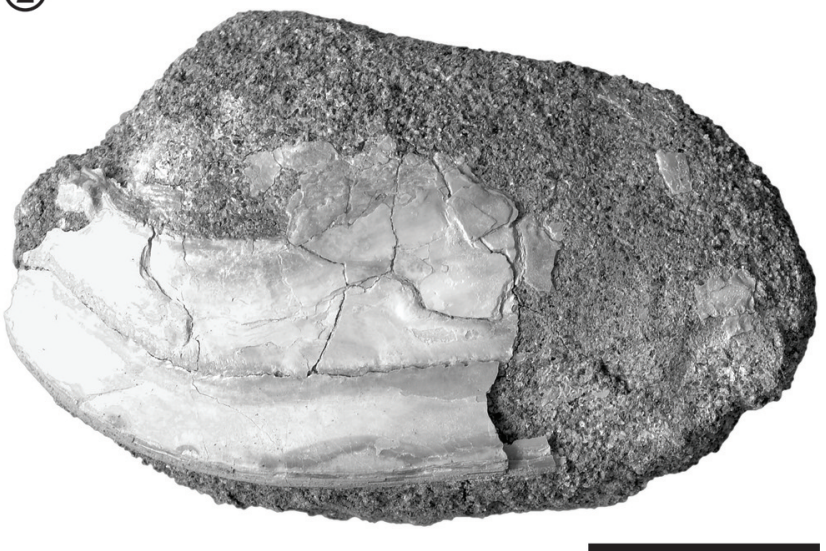

(4)

(5)
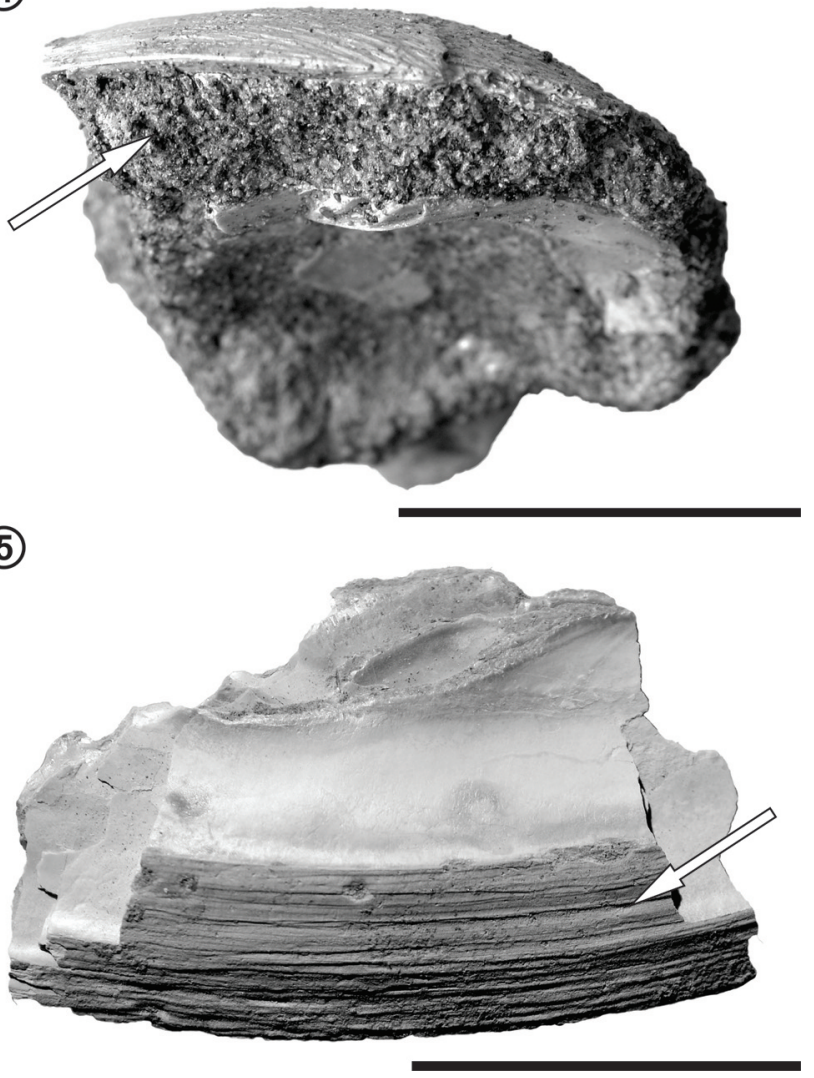

Figure 3. 1-5, Diplodon cf. colhuapiensis Ihering, MPM-Pi 19425 (specimens from Estancia Santa Lucía); 1, lateral (left) and dorsal view (specimen a), the arrow points to the remains of the pearly layer; 2 , lateral (left) view (specimen b); $\mathbf{3}$, lateral (left) and dorsal view (specimen c); $\mathbf{4}$, umbonal fragment of the left valve (specimen d), arrow points to the expansive sedimentary filling; 5 , lateral external fragment of valve (specimen e), arrow points to the regular commarginal lines in the ventral margin of the shell. Scale bars $=2 \mathrm{~cm}$. 
mens. The species remains in open nomenclature until better material becomes available.

Regarding the specimens from Río Sehuen (MACN-Pi 296), they are clearly different from MPM-Pi 19425 in shell size. Although the general morphology is similar, the specimens from Río Sehuen are considerably smaller (length of 51 to $38 \mathrm{~mm}$, height of 28 to $20 \mathrm{~mm}$, width of 18 to $10 \mathrm{~mm}$ ). These size differences could be considered as within the natural range part of the species given that the three studied samples (MPM-Pi 19425, MACN-Pi 295 and
MACN-Pi 296) share the same high/length ratio of $\sim 0.57$. There are specimens that are assigned to $D$. aff. colhuapiensis from the Norquinco Formation, nearby the town of Arroyo Horqueta, Province of Chubut (Morton and Sepúlveda, 1988), based on the form of their valve and, particularly, on the previous depression close to the umbo. These features, together with the image illustrated in Morton and Sepúlveda (1988), do not allow assuring an accurate assignment to the species nominated by lhering (1903).

Taking into account what occurs in the extant popula-
(1)

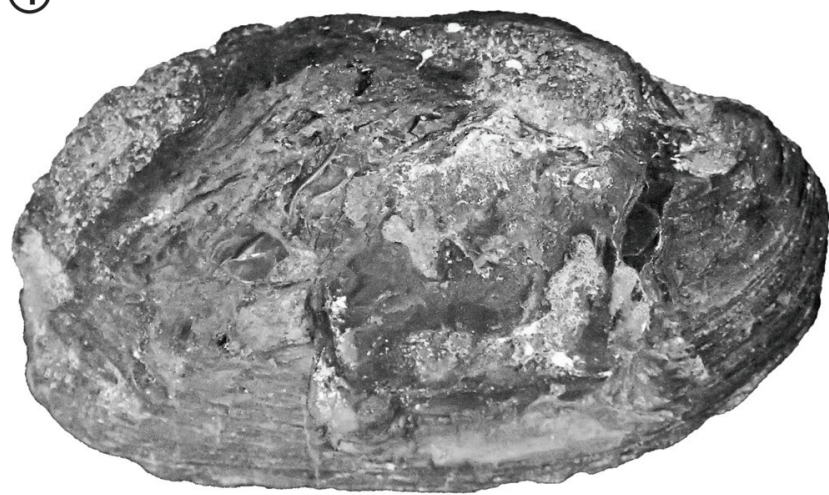

(2)

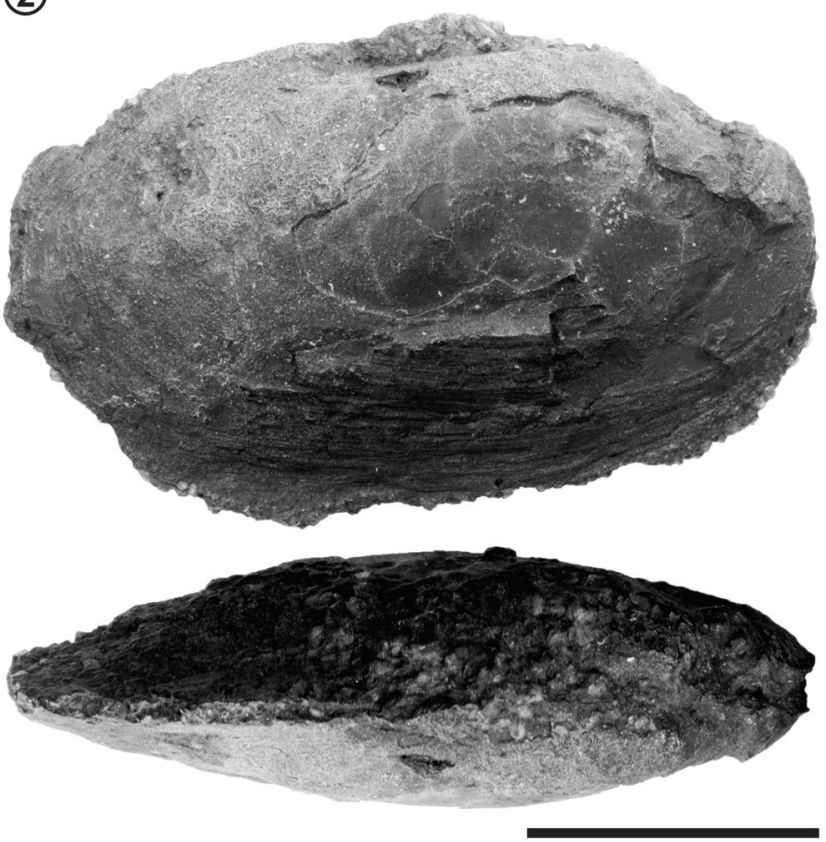

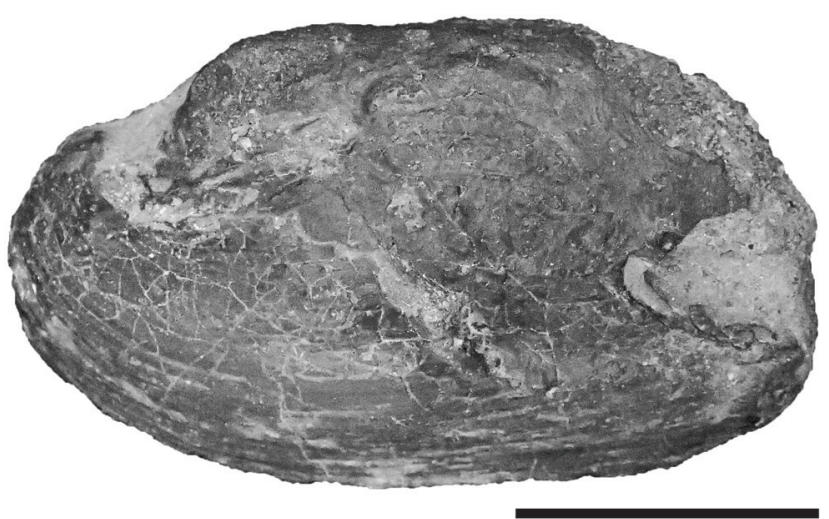

(3)
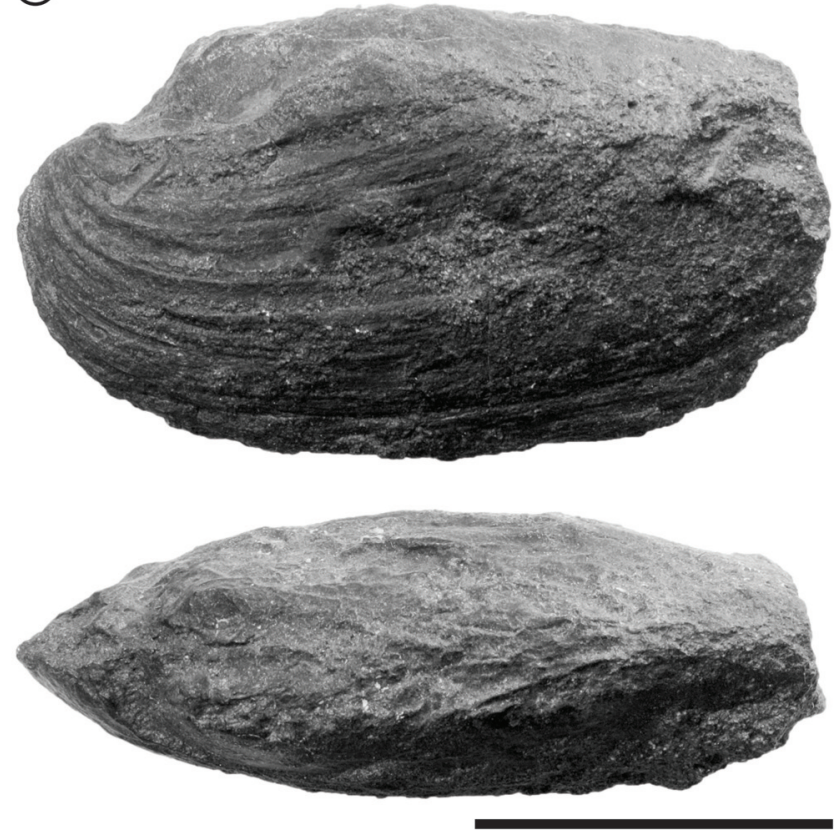

Figure 4. 1-3, Diplodon colhuapiensis Ihering; 1, lateral views of specimen CM 61-137 (Holotype); 2-3, two specimens, MACN-Pi 295 (Paratypes?); 2, lateral (right) and dorsal view of an internal mold and fragments of shell; $\mathbf{3}$, lateral (left) and dorsal view of specimen, showing the commarginal lines. Scale bars $=2 \mathrm{~cm}$. 
tions of Diplodon species, and knowing the existing interpopulation differences within this group of freshwater bivalves, already noticed in the Río Paraná basin (Bonetto and Ezcurra de Drago, 1966), we can expect a variation in size among the individuals of their fossil populations. This would be particularly possible in the case of remains found in different locations and stratigraphic levels in very distant localities, as it happens among the specimens found in northern and southernmost ends of Patagonia.

Sedimentological context. The stratigraphic level of Barrancas Blancas at Estancia Santa Lucía that yielded the specimens of Diplodon is approximately $90 \mathrm{~m}$ above the contact with the underlying Monte León Formation, and about $60 \mathrm{~m}$ above a tuff dated in 17.04 $\pm 0.55 \mathrm{Ma}$ (Cuitiño et al., 2016)

(Fig. 2.1,3). The stratigraphic correlation of this location, using the guide levels in the field, suggests its correspondence with the middle section of Barrancas Blancas, which was measured by Fernicola et al. (2014).

The remains of Diplodon are concentrated near the base of the section, in a medium grain-size sandstone bed (Fig. 2.2), 20 cm thick, with irregular erosive surface. The specimens are mostly preserved as articulated valves with their internal space filled with sediments from the surrounding matrix. These shells show no evidence of bioerosion, encrustation and/or fragmentation, although relicts of the internal nacreous layers of the shells are frequent. The shells are articulated, with random orientation, although a few specimens show the commissure plane perpendicular to the stratification with complete and fragmentary remains associated in the same level (Fig. 2.2). Towards the top of the fossil bed, the siltstones display a finning upward trend, with abundant rhizoliths and yellowish ochre coloration. Finally, the base of the fossiliferous bed is irregular and discordant over a brown claystone level, which, in turn, overlays on a bed of yellowish siltstones with abundant ochre rhizoliths.

Under the petrographic microscope, the rock bearing the fossil remains of Diplodon is a sandstone dominated by angular clasts of mainly volcanic lithics of andesitic composition with pilotaxitic texture (Fig. 5.1-2) and, to a lesser extent, by sedimentary lithic weathered clasts and acid volcanic lithics with felsitic texture clasts. Among the crystalloclasts of the sedimentary matrix, there are predominantly volcanic type quartz with limpid extinction, feldspars and slightly to moderately weathered plagioclase. The clasts have dense clay coating; a dense filling of compact and laminated clay completely obliterates the pore space (Fig. 5.1-2). This illuvial clay is light brown (with a low luminosity when seen under polarized light) probably due to the mixing between clay and organic matter.
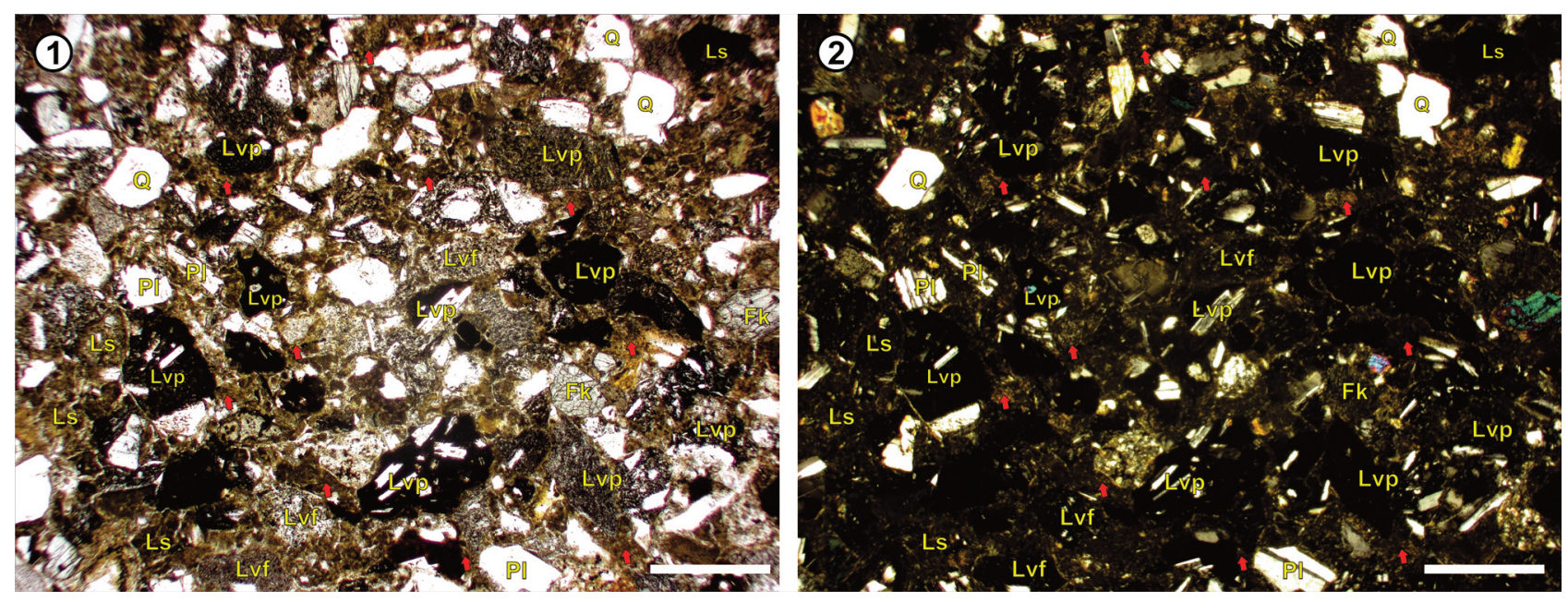

Figure 5. Thin-section photomicrographs of the matrix of Diplodon remains. 1, plane-polarized light. 2, cross-polarized light; Fk, potassium feldspar; Ls, sedimentary lithic; Lvf, volcanic lithic with felsic texture; Lvp, volcanic lithic with pilotaxic texture; PI, plagioclases; Q, Clast composition includes quartz. Scale bars $=500 \mu \mathrm{m}$. 


\section{DISCUSSION}

The abundance and taxonomic diversity of the fossil record of vertebrates found in the SCF contributed to characterize the paleocommunities and paleoclimate of southern Patagonia during the Burdigalian (see Kay et al., 2012). By contrast, reports of macroinvertebrates have been scarce and fragmentary. Only a few references dealt with bivalves typical of marine-marginal environments (Griffin and Parras, 2012; Rodríguez et al., 2012). These came from the lower parts of the SCF in the transition with the underlying Monte León Formation, a typically marine lower Miocene unit (Parras et al., 2012). In this sense, the record of Diplodon specimens (MPM-Pi 19425), reported from the upper beds of the Estancia Santa Lucia section, contributes with new information to the characterization of the SCF.

The Nayades or "Almejas Nacaríferas", as called by Ageitos de Castellanos (1960), are freshwater bivalves that show a wide regional distribution in southern South America (Miyahira et al., 2017). Unionids from the Argentine Patagonia are represented by the Hyriidae, with the genus Diplodon, and the Mycetopodidae, with the genus Anodontites. Populations of these genera are well-established in northern Patagonia, with species inhabiting cordilleran areas and the extra-Andean sector of Argentina (Parodiz, 1969; Torres et al., 2013). They inhabit clear lentic lakes or lotic water from small streams to large rivers tolerating coarse-grained substrates but preferring fine-grained sediments (usually rich in organic matter). For example, the species $D$. chilensis inhabits lentic and lotic waters of the Manso basin that drain into the Pacific Ocean (Bonetto, 1973). In addition, they are commonly seen in shallow waters, close to $30 \mathrm{~cm}$ deep (Miyahira et al., 2017), or in association with roots of aquatic plants (Avelar and Cunha, 2009).

The Family Hyriidae is represented in Argentina by two genera, Castalia and Diplodon. The latter is marked by a large number of nominal species in the Argentine territory, which inhabit mainly the "del Plata" basin (Torres et al., 2013). In this region, the greatest diversity of Diplodon is found in the upper basin of Río Paraná, in which the waters are relatively clear, becoming increasingly turbid towards the distal zone where the bottoms are mostly muddy (Bonetto and Ezcurra de Drago, 1966). These conditions are also found in northwestern Patagonia, where the species inhabit similar waters to those of the upper Río Paraná. Diplodon (Diplodon) chilensis (Gray, 1828) is the most widely distributed species, and it is recorded in the provinces of Neuquén, Río Negro, and Chubut as well as in part of the Chilean territory, shared with Argentina, in the Auraucana subregion (Bonetto, 1973). Dense populations of this species inhabit lentic water courses in cordilleran lakes (Bonetto, 1973), such as the forested region of Lago Futalaufquen ( $42^{\circ} 49^{\prime} 00^{\prime \prime}$ S; $71^{\circ}$ $\left.43^{\prime} 00^{\prime \prime} 0\right)$, in which the southermmost records of this taxon can be found (Ageitos de Castellanos, 1959, 1960). The genus Anodontites is represented by the species Anodontites (Anodontites) patagonicus (Lamarck, 1819). This species lives in more restricted areas, only present in the Argentine territory, mainly in lotic environments (Bonetto,

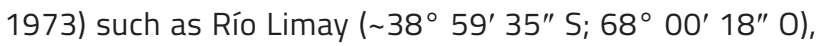
between the provinces of Neuquén and Río Negro (Bonetto, 1973; Torres et al., 2018, see map).

The record of $D$. cf. colhuapiensis, in Barrancas Blancas, extends the distribution range of the species several degrees southward, from Lago Colhue Huapi, between $45^{\circ}-$ $46^{\circ} \mathrm{S}$ (from where the holotype of the species comes from; Ihering, 1903) to $50^{\circ} 12^{\prime} 58.5^{\prime \prime} \mathrm{S}$. This partially supports the doubtful record mentioned by Parodiz (1969, see map p. 50) for the Oligocene? of Isla Grande of Tierra del Fuego. On the other hand, D. cf. colhuapiensis of SCF is consistent with the water courses inferred for the upper levels of this unit in previous sedimentological studies (Fernicola et al., 2014), which were confirmed by the presence of dense well-established populations of "Nayades" inhabiting the bottoms of these paleoenvironments.

In accordance with the general ecological requirements of this group of freshwater bivalves, the presence of this taxon enables the supposition that in the fluvial watercourses of the SCF, marginal protected areas could probably have been found (backwaters), including the variety of environments in which the extant Diplodon (Diplodon) chilensis currently lives. In these environments, the input of sediments transported by low-energy agents is evidenced in the sedimentary matrix of the bearing deposit of this monospecific population of freshwater bivalves. 


\section{Temporal interpretation}

The label on the material of $D$. colhuapiense, MACN-Pi 295 (of which the holotype CM 61-137 was most probably part), states that it came from the Pyrotherium beds originally regarded as Cretaceous in age. Nevertheless, the Pyrotherium beds have been assigned to the Deseadan SALMA (Flynn et al., 2003), for which an Oligocene age of 29.4-24.2 Ma has been estimated (Dunn et al., 2013). Therefore, the age of the specimens MACN-Pi 295 and the holotype CM 61-137 would be Rupelian-Chattian.

MACN-Pi 296, referred in the labels as "Sehuenian (Late Cretaceous)", could either be from the Mata Amarilla Formation (Cretaceous) or from the Santa Cruz Formation (Miocene). However, the Sehuenian of Ameghino (1906) only included marine sediments. This suggests that MACNPi 296 should come from the Santa Cruz Formation with continental deposits. In addition, it is similar in morphology to the Santacrucian specimens herein described (although the specimens MACN-Pi 296 are smaller). This would agree with the records of Diplodon colhuapiensis being restricted to the Cenozoic, after the reinterpretation of the age of the type material. Then, if our interpretation of the age of MACNPi 296 is correct, the fossil record of Diplodon colhuapiensis and D. cf. colhuapiensis (MPM-Pi 19425) would not include the Mesozoic and would be restricted to the DeseadanSantacrucian SALMA (Oligocene-Miocene).

\section{Interpretation of the sedimentary environment}

Due to the abundance of fine-grained deposits with evidence of subaerial exposure (e.g., root traces and sandy paleochannels), the SCF is interpreted as resulting from the accumulation in a low-energy fluvial environment (Fernicola et al., 2014; Cuitiño et al., 2019). In particular, the beds bearing Diplodon cf. colhuapiensis correspond to a thin sandy level with an erosive base intercalated in mudstone deposits with rhizoliths which suggest it was deposited in fluvial floodplains. This layer shows a lobe-shape geometry and is interpreted as the deposition of overflow channels (i.e., crevasse splay deposits) on the floodplains during episodes of high discharge or river avenues (Mjøs et al., 1993; Bridge, 2003). After their accumulation, these deposits underwent subaerial exposure developing pedogenesis, which is evidenced by illuvial type argillic cement that fills the pore spaces and root traces (Bullock et al., 1985; Retallack, 2001). This supports the interpretation of a proximal floodplain environment. Thick sandstones are scarce in the SCF, in the eastern (middle-distal) basin (Fig. 2.1), and they have been recorded only near the base of some paleochannels. The existence of various specimens of articulated bivalves, chaotically arranged, suggests at least a minimum transport from where they lived (source area). On the other hand, the internal filling of these specimens, which is similar to the surrounding sediment, supports the idea that the individuals were removed from their natural habitat and redeposited in life by means of a high energy current which caused their death during the removal, accumulation and final suffocation processes. This type of flow with erosion capacity is relatively common in anastomosed medium-distal fluvial systems (Miall, 1996; Bridge, 2003) such as those represented in the SCF (Fernicola et al., 2014; Raigemborn et al., 2015; Cuitiño et al., 2016), especially when overflows of the fluvial channels occur and cause overflow or crevasse events on the proximal floodplains. The floodplains recorded in the SCF are composed mainly of yellowish tuffs and siltstones with ochre rhizoliths suggesting a subaerial, well oxygenated environment with vegetation development. As well, a few levels indicate stagnant water accumulation. Because of this, we infer that Diplodon cf. colhuapiensis would have inhabited marginal protected areas (backwaters) of the fluvial channels in anastomosed rivers and that, due to an overflow process, these were removed and accumulated rapidly in the floodplains.

\section{CONCLUSIONS}

This is the first report of freshwater bivalves for the Early-Middle Miocene SCF, in part probably corresponding to the records originally assigned to the "Sehuenense stage" (piso Sehuenense of F. Ameghino), represented by specimens referred to Diplodon cf. colhuapiensis Ihering, 1903. The existence of an established population of mollusks of the Family Hyriidae in the upper-middle beds of the SCF, preserved in fluvial overflow deposits, suggests the existence of well-developed freshwater courses during the deposition of the unit. These deposits are interpreted as fluvial floodplains with evidence of fluvial avenues that excavated the substrate and removed the malacofauna that inhabited the 
fluvial channels of the SCF. The identification of the genus validates its presence in the lower Miocene and extends its southern distribution to the latitude of Río Santa Cruz ( 50 S), as already stated by Parodiz (1969). Finally, new specimens of Diplodon cf. colhuapiensis, from the SCF, showing a better preservation, would enable the establishment of a more precise identification.

\section{ACKNOWLEDGEMENTS}

To the owners and personnel of the farms who allowed the team to work on their lands. To the Carnegie Museum of Natural History, and to T.A. Pearce, and C.F. Sturm, for permitting the use of holotype images of $D$. colhuapiensis. To C.J. del Río, for providing us access to the invertebrate paleontology collection of the MACN. To M.O. Manceñido, G. Pastorino, and S. Torres, for sharing some of the bibliographic material required for our research. To C. Deschamps, and M. Griffin, for reading the manuscript. To the referees and the PE-APA editorial committee, for their comments and suggestions. To the government of the Province of Santa Cruz and Museo Regional Provincial P.M.J. Molina of Río Gallegos (Santa Cruz, Argentina) for granting us access to field work and the collection of fossils in the provincial territory. This work is a contribution to the projects PIP 100-523, CONICET- PIP 00781; UNLP N/867; ANPCyTPICT 2013-0389 and 2017-1081; National Science Foundation EAR0851272, EAR1348259 and EAR1349749; and National Geographic Society 9167-12, granted to S. F. Vizcaíno, M. S. Bargo, J. C. Fernicola, and R.F. Kay.

\section{REFERENCES}

Ageitos de Castellanos, Z.J. 1959. Algunas consideraciones sobre el género Diplodon. Notas Museo de La Plata (Zoología) 19: 243-245.

Ageitos de Castellanos, Z.J. 1960. Almejas nacaríferas de la República Argentina. Género Diplodon (Moll. Mutélidos). Secretaría de Estado de Agricultura y Ganadería de la Nación. Dirección general de pesca y conservación de la fauna. Miscelánea 421: 40 p.

Ameghino, F. 1893. Sobre la presencia de vertebrados de aspecto mesozoico en la formación Santacruceña de la Patagonia austral. Revista del Jardín Zoológico de Buenos Aires 1: 76-84.

Ameghino, F. 1906. Les formations sédimentaires du Crétacé Superieur et du Tertiaire de Patagonia. Anales del Museo Nacional de Buenos Aires (serie 3) 8: 1-568.

Arbe, H.A. 1989. Estratigrafía, discontinuidades y evolución sedimentaria del Cretácico en la Cuenca Austral, Provincia de Santa Cruz. In: G. Chebli, and L.A. Spalletti (Eds.), Cuencas Sedimentarias Argentinas. Serie de Correlación Geológica 6, Instituto Superior de Correlación Geológica, Tucumán, p. 419-442.

Arbe, H.A. 2002. Análisis estratigráfico del Cretácico de la Cuenca Austral. In: M.J. Haller (Ed.), Geología y Recursos Naturales de Santa Cruz. Relatorio $15^{\circ}$ Congreso Geológico Argentino. Asociación Geológica Argentina, Ciudad Autónoma de Buenos Aires, p. $103-128$.

Avelar, W.E.P., and Cunha, A.D. 2009. The anatomy and functional morphology of Diplodon rhombeus fontainianus (Orbigny, 1835) (Mollusca, Bivalvia, Hyriidae). Brazilian Journal of Biology 69: 1153-1163.

Bonetto, A.A. 1973. Nayades de la Patagonia. Revista de la Asociación de Ciencias Naturales del Litoral 4: 177-185.
Bonetto, A.A., and Ezcurra de Drago, I. 1966. Notas malacológicas 4. 1) Moluscos paranenses en aguas uruguayas y del sur del Brasil. 2) Notas sobre desoves de algunos gastropodos dulceacuícolas. Physis 13: 121-127.

Bostelmann, J.E., Le Roux, J.P., Vásquez, A., Gutiérrez, N.M., Oyarzún, J.L., Carreño, C., Torres, T., Otero, R., Llanos, A., Fanning, C.M., and Hervé, F. 2013. Burdigalian deposits of the Santa Cruz Formation in the Sierra Baguales, Austral (Magallanes) Basin: age, depositional environment and vertebrate fossils. Andean Geology 40: 458-489.

Brea, M., Zucol, A.F., Bargo, M.S., and Vizcaíno, S. 2017. First Miocene record of Akaniaceae in Patagonia (Argentina): a fossil wood from the Early Miocene Santa Cruz Formation and its palaeobiogeographical implications. Botanical Journal of the Linnean Society 183: 334-347.

Bridge, J.S. 2003. Rivers and Floodpplains: Forms, Processes, and Sedimentary Record. Blackwell Science Publishing, Oxford, 491 p.

Bullock, P., Fedoroff, N., Jongerius, A., Stoops, G., and Tursina, T. 1985. Handbook for Soil Thin Section description. Waine Research Publication, United Kingdom, 152 p.

Cuitiño, J.I., Fernicola J.C., Kohn, M., Kay, R.F., Trayler, R., Naipauer, M., Bargo, M.S., and Vizcaíno, S.F. 2016. U-Pb geochronology of the Santa Cruz Formation (early Miocene) at the Río Bote and Río Santa Cruz (southernmost Patagonia, Argentina): implications for the correlation of fossil vertebrate localities. Journal of South American Earth Sciences 70: 198-210.

Cuitiño, J.I., Fernicola, J.C., Raigemborn, M.S., and Krapovickas, V. 2019. Stratigraphy and depositional environments of the Santa Cruz Formation (Early-Middle Miocene) along the Río Santa Cruz, southern Patagonia, Argentina. In: J.C. Fernicola, M.S. Bargo, S.F. Vizcaíno, and R.F. Kay (Eds.), Early-Middle Miocene Paleontology in the Río Santa Cruz, Southern Patagonia, Argentina. 130 years since Ameghino, 1887. Publicación Electrónica de la Asociación Paleontológica Argentina 19: 14-33.

Cuitiño, J.I., Pimentel, M.M., Ventura Santos, R., and Scasso, R.A. 2012. High resolution isotopic ages for the "Patagoniense" transgression in southwest Patagonia: stratigraphic implications. Journal of South American Earth Sciences 38: 110-122.

Cuitiño, J.I., and Scasso, R.A. 2010a. Sedimentología y paleoambientes del Patagoniano y su transición a la Formación Santa Cruz al sur del Lago Argentino, Patagonia Austral. Revista de la Asociación Geológica Argentina 66: 406-417.

Cuitiño, J.l., and Scasso, R.A. 2010b. Large scale, cross-bedded sandstone bodies in a Cenozoic, tide-dominated embayment. $18^{\text {th }} \mathrm{In}$ ternational Sedimentological Congress (Mendoza), Acta digital.

Dunn, R.E., Madden, R.H., Kohn, M.J., Schmitz, M.D., Strömberg, C.A., Carlini, A.A., Ré, G.H., and Crowley, J. 2013. A new chronology for middle Eocene-early Miocene South American land mammal ages. Geological Society of America Bulletin 125: 539-555.

Fernicola, J.C., Bargo, M.S., Vizcaíno, S.F., and Kay, R.F. 2019. Historical background for a revision of the paleontology of the Santa Cruz Formation (Early-Middle) along the Río Santa Cruz, Patagonia, Argentina. In: J.C. Fernicola, M.S. Bargo, S.F. Vizcaíno, and R.F. Kay (Eds.), Early-Middle Miocene Paleontology in the Rio Santa Cruz, Southern Patagonia, Argentina. 130 years since Ameghino, 1887. Publicación Electrónica de la Asociación Paleontológica Argentina 19: 1-13.

Fernicola, J.C., Cuitiño, J.I., Vizcaíno, S.F., Bargo, M.S., and Kay, R.F. 2014. Fossil localities of the Santa Cruz formation (early Miocene, Patagonia, Argentina) prospected by Carlos Ameghino in 1887 revisited and the location of the Notohippidian. Journal of South American Earth Sciences 52: 94-107. 
Feruglio, E. 1938. Relaciones estratigráficas entre el Patagoniano y el Santacruciano en la Patagonia Austral. Revista del Museo de La Plata (Geología) 4: 129-159.

Feruglio, E. 1949. Descripción Geológica de la Patagonia. Dirección General de Yacimientos Petrolíferos Fiscales, Buenos Aires. Tomos: 1: 1-323; 2: 1-349; 3: 1-331.

Flynn, J.J., Wyss, A.R., Croft, D.A., and Charrier, R. 2003. The Tinguiririca Fauna, Chile: biochronology, paleoecology, biogeography, and a new earliest Oligocene South American Land Mammal "Age". Palaeogeography, Palaeoclimatology, Palaeoecology 195: 229-259.

Fossa Mancini, E., Feruglio, E., and Yussen de Campana, J.C. 1938. Una Reunión de geólogos de Y.P.F. y el problema de la Terminología Estratigráfica. Boletín de Informaciones Petroleras 171: 31-95.

Ghiglione, M.C., Ramos, V.A., Cuitiño, J., and Varberón, V. 2016. Growth of the Southern Patagonian Andes $\left(46-53^{\circ} \mathrm{S}\right)$ and their Relation to Subduction Processes. In: A. Folguera, M. Naipauer, L. Sagripanti, M.C. Ghiglione, D.L. Orts, and L. Giambiagi (Eds.), Growth of the Southern Andes. Springer Earth Systems Sciences, Switzerland, p. 201-240.

Griffin, M., and Parras, A. 2012. Oysters from the base of the Santa Cruz Formation (late Early Miocene) of Patagonia. In: S.F. Vizcaíno, R.F. Kay, and M.S. Bargo (Eds.), Early Miocene Paleobiology in Patagonia: high-latitude paleocommunities of the Santa Cruz Formation. Cambridge University Press, Cambridge, p. 83-90.

Hatcher, J.B. 1900. Sedimentary rocks of southern Patagonia. American Journal of Science (1880-1910), Serie 4 9: 85-108.

Ihering von, H. 1903. Les mollusques des terrains crétaciques supérieurs de L'Argentine orientale. Anales del Museo Nacional de Buenos Aires, Serie 3 2: 193-228.

Ihering von, H. 1907. Les mollusques fossiles du Tertiaire et du Crétacé supérieur de L'Argentine. Anales del Museo Nacional de Buenos Aires, Serie 3 7: 1-608.

Ihering von, H. 1914. Catalogo do Molluscos cretáceos e terciarios da argentina da collecção do autor. Notas Preliminares. Revista do Museu Paulista 1: 1-113.

Kay, R.F., Vizcaíno, S.F., and Bargo, M.S. 2012. A review of the paleoenvironment and paleoecology of the Miocene Santa Cruz Formation. In: S.F. Vizcaíno, R.F. Kay, and M.S. Bargo (Eds.), Early Miocene Paleobiology in Patagonia: high-latitude paleocommunities of the Santa Cruz Formation. Cambridge University Press, Cambridge, p. 331-365.

Krapovickas, V. 2012. Ichnology of distal overbank deposits of the Santa Cruz Formation (late Early Miocene): paleohydrologic and paleoclimatic significance. In: S.F. Vizcaíno, R.F. Kay, and M.S. Bargo (Eds.), Early Miocene Paleobiology in Patagonia: high-latitude paleocommunities of the Santa Cruz Formation. Cambridge University Press, Cambridge, p. 91-103.

Manceñido, M.O., and Damborenea, S.E. 1984. Megafauna de invertebrados paleozoicos y mesozoicos. $9^{\circ}$ Congreso Geológico Argentino (San Carlos de Bariloche), Relatorio 2-5: 413-465.

Matheos, S.D., and Raigemborn, M.S. 2012. Sedimentology and paleoenvironment of the Santa Cruz Formation. In: S.F. Vizcaíno, R.F. Kay, and M.S. Bargo (Eds.), Early Miocene Paleobiology in Patagonia: high-latitude paleocommunities of the Santa Cruz Formation. Cambridge University Press, Cambridge, p. 59-82.

Miall, A.D. 1996. The geology of fluvial deposits. Sedimentary facies, basin analysis, and petroleum geology. Springer-Verlag, Berlin, $582 \mathrm{p}$.

Miyahira, I.C., Barbosa dos Santos, S., and Dreher Mansur, C. 2017. Freshwater mussels from South America: state of the art of Unionida, especially Rhipidodontini. Biota Neotropica 17 doi:
10.1590/1676-0611-BN-2017-0341

Miyahira, I.C., Dreher Mansur, M.C., and Barbosa dos Santos, S. 2013. Revision of the type specimens of Diplodon ellipticus and Diplodon expansus (Bivalvia, Unionoida, Hyriidae). Spixiana 36: $173-182$.

Mjøs, R., Walderhaug, O., and Prestholm, E. 1993. Crevasse splays sandstone geometries in the Middle Jurassic Ravenscar Group Yorkshire, UK. In: M. Marzo, and C. Puigdefáfregas (Eds.), Alluvial Sedimentation. International Association of Sedimentologists, Special Publication 17: 167-184.

Montalvo, C.I., Raigemborn, M.S., Tomassini, R.L., Zapata, L., Bargo M.S., Martínez Uncal, M.C., and Vizcaíno, S.F. 2019. Floodplain taphonomic mode of Early Miocene vertebrates of southern Patagonia, Argentina. Palaios 34: 105-120.

Morton, L.S., and Sepúlveda, E.G. 1988. Bivalvos dulceacuícolos de la Formación Ñorquinco (Oligoceno), en la Cuenca del Río Percey, Provincia del Chubut, Argentina. Ameghiniana 25: 149-154.

O'Gorman, J.P., and Varela, A.N. 2010. The oldest lower Upper Cretaceous plesiosaurs (Reptilia, Sauropterygia) from the southern Patagonia, Argentina. Ameghiniana 47: 447-459.

Parodiz, J.J. 1969. The Tertiary non-marine Mollusca of South America. Annals of Carnegie Museum 40: 5-237.

Parras, A., Dix, G., and Griffin, M. 2012. Sr-isotope chronostratigraphy of Paleogene Neogene marine deposits: Austral Basin, southern Patagonia (Argentina). Journal of South American Earth Sciences 37: 122-135.

Parras, A., and Griffin, M. 2013. Late Cretaceous (Campanian/Maastrichtian) freshwater to restricted marine mollusc fauna from the Loncoche Formation, Neuquén Basin, west-central Argentina. Cretaceous Research 40: 190-206.

Pascual, R., Ortega Hinojosa, E.J., Gondar, D., and Tonni, E.P. 1965. Las Edades del Cenozoico mamalífero de la Argentina, con especial atención a aquellas del territorio bonaerense. Anales de la Comisión de Investigaciones Científicas de la Provincia de Buenos Aires 6: 165-193.

Perkins, M.E., Fleagle, J.G., Heizler, M.T., Nash, B., Bown, T.M., Tauber, A.A., and Dozo, M.T. 2012. Tephrochronology of the Miocene Santa Cruz and Pinturas Formations, Argentina. In: S.F. Vizcaíno, R.F. Kay, and M.S. Bargo (Eds.), Early Miocene Paleobiology in Patagonia: high-latitude paleocommunities of the Santa Cruz Formation. Cambridge University Press, Cambridge, p. 23-40.

Raigemborn, M.S., Krapovickas, V., Beilinson, E., Peral, L.E.G., Zucol, A.F., Zapata, L., and Sial, A.N. 2018. Multiproxy studies of Early Miocene pedogenic calcretes in the Santa Cruz Formation of southern Patagonia, Argentina indicate the existence of a temperate warm vegetation adapted to a fluctuating water table. Palaeogeography, Palaeoclimatology, Palaeoecology 500: 1-23.

Raigemborn, M.S., Krapovickas, V., Zucol, A., Zapata, L., Beilinson, E., Toledo, N., Perry, J., Lizzoli, S., Martegani, L., Tineo, D., and Passeggi, E. 2019. Paleosols and related soil-biota of the early Miocene Santa Cruz Formation (Austral-Magallanes basin, Argentina): a multidisciplinary approach to reconstructing ancient terrestrial landscapes. Latin American Journal of Sedimentology and Basin Analysis 25: 117-148.

Raigemborn, M.S., Matheos, S.D., Krapovickas, V., Vizcaíno, S.F., Bargo, M.S., Kay, R.F., Fernicola, J.C., and Zapata, L. 2015. Paleoenvironmental reconstruction of the coastal Monte León and Santa Cruz formations (Early Miocene) at Rincón del Buque, Southern Patagonia: A revisited locality. Journal of South American Earth Sciences 60: 31-55.

Retallack, G.J. 2001. Soils of the Past: An introduction to Paleope- 
dology. Blackwell Science Ltd., Oxford, 404 p.

Rodríguez, P.E., Miquel, S.E., Tauber, A.A., and Krapovickas, J.M. 2012. First record of land gastropods of the family Charopidae in the Early to Middle Miocene from Santa Cruz Province, Southern Patagonia, Argentina (Gastropoda Pulmonata, Stylommatophora, Charopidae). Archiv für Molluskenkunde: International Journal of Malacology 141: 57-66.

Schneider, C.A., Rasband, W.S., and Eliceiri, K.W. 2012. NIH Image to ImageJ: 25 years of image analysis. Nature Methods 9: 671-675.

Tauber, A. 1994. [Estratigrafía y vertebrados fósiles de la Formación Santa Cruz (Mioceno Inferior) en la costa Atlántica de Santa Cruz, República Argentina. Tesis Doctoral, Facultad de Ciencias Exactas y Naturales, Universidad Nacional de Córdoba, 422 p. Inédita.].

Tauber, A.A. 1997. Bioestratigrafía de la Formación Santa Cruz (Mioceno Inferior) en el extremo sudeste de la Patagonia. Ameghiniana 34: 413-426.

Torres, S., Cao, L., Gutiérrez Gregoric, D.E., de Lucía, M., Brea, F., and Darrigran, G. 2018. Distribution of the Unionida (Bivalvia, Paleoheterodonta) from Argentina and its conservation in the Southern Neotropical Region. Plos One doi: 10.1371/journal. pone.0203616

Torres, S., Darrigran, G., and Damborenea, C. 2013. Distribución del género Diplodon (Mollusca, Bivalvia, Hyriidae) en la Cuenca del Plata (Argentina) mediante el uso de Colecciones Biológicas. AUGMIDOMUS Revista Electrónica del Comité de Medio Ambiente 5: 90-99.

Varela, A.N., Poiré, D.G., Martin, T., Gerdes, A., Goin, F.J., Gelfo, J.N., and Hoffmann, S. 2012. U-Pb zircon constraints on the age of the Cretaceous Mata Amarilla Formation, Southern Patagonia, Argentina: its relationship with the evolution of the Austral Basin. Andean Geology 39: 359-379.
Vizcaíno, S.F., Bargo, M.S., and Fernicola, J.C. 2013. Expediciones paleontológicas durante los siglos 19 y 20 a la Formación Santa Cruz (Mioceno Inferior, Patagonia) y destino de los fósiles. $3^{\circ}$ Congreso Argentino de Historia de la Geología (Salta), Actas: 231-246.

Wagner, J.A. 1827. Testacea fluviatilia quae in itinere per Brasiliam annis 1817-1820 jussu et auspiciis Maximiliani Josephi I. Bavariae Regis augustissimi suscepto, collegit et pingenda curavit Dr. J.B. de Spix, digessit, descripsit et observationibus illustravit Dr. J.A. Wagner. Monachii. Wolf, p. 1-4, 1-36, Tab. 1-29.

Zapata, L., 2018. [Estudio paleoambiental de la Formación Santa Cruz (Mioceno inferior-medio) entre los ríos Coyle y Gallegos, Patagonia Austral, Argentina. Tesis Doctoral, Facultad de Ciencias Naturales y Museo, Universidad Nacional de La Plata, 304 p. Inédita.].

Zapata, L., Krapovicas, V., Raigenborn, M.S., and Matheos, S. 2016. Bee cell trace fossils associations on paleosols from the Santa Cruz Formation: Palaeoenvironmental and palaeobiological implications. Palaeogeography, Palaeoclimatology, Palaeoecology 459: 153-169.

Doi: 10.5710/PEAPA.16.07.2019.283

Recibido: 15 de marzo 2019

Aceptado: 16 de julio 2019 